\title{
Biocementation Potential Of Tropical Residue Soil Infused With Facultative Anaerobe Bacteria
}

\author{
Kenny Tiong Ping Chiet ${ }^{1, a}$, Khairul Anuar Kassim ${ }^{1, b^{*}}$, Siaw Yah Chong ${ }^{1, c}$ \\ ${ }^{1}$ Faculty of Civil Engineering, Universiti Teknologi Malaysia.81300, Johor Bahru, Malaysia

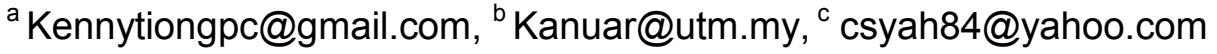

Keywords: Biomediated soil improvement, facultative anaerobe bacteria, tropical residue soil, Bacillus Subtilis, microbial induced calcite precipitation (MICP), group improvement

\begin{abstract}
Biomediated soil improvement, a promising new branch of microbial geotechnology; which involved multi disciplines has successfully attracted abundant attentions among researchers, geotechnical engineers, and other industries practitioners. Few of the researches were conducted to examine the potential implementation of this technique on tropical residue soil. However, the uncertainties outcomes and inconsistency of bio mediated soil improvement, especially on the clayed soil have made this technique remained at the laboratory stage. Therefore, this paper intended to provide better understanding of this technique by investigating the relation between the bacteria, cementation reagents, and tropical residue soil. The residual soil was mixed with facultative anaerobe bacteria, Bacillus subtilis before it was compacted into a prefabricated PVC mould. The soil samples were treated with different treatment condition such as (1) control or untreated, (2) treated with cementation solution, (3) treated with bacteria only, and (4) treated with bacteria and Cementation reagent. A worth noting finding showed that the sample treated with bacteria and nutrient only has produced the highest increment of shear strength. This phenomenon might have been caused by the effect of the chemical reagent to the mineralogy of residue soil. The presence of the chemical reagents is believed to have weakened the shear strength of the tropical residual soil.
\end{abstract}

\section{Background of study/Introduction}

Biomediated soil stabilization or similarly known as Microbial- induced calcite precipitation (MICP), an emerging discipline of soil improvement in geotechnical engineering. This MICP technique integrated with microorganism and chemical reagents to create a more environmental friendly soil improvement technique by forming the microbial induced calcite precipitation.

However, exposure to the byproduct of this MICP technique such as concentrated ammonium, and oxidized by-product nitrate are dangerous and may impair the environmental and mankind[1, 2]; Therefore, in order to address its limitations, many effort and researches have been conducted and developed rapidly over the years [3-6]. Initially, most of the MICP researches were merely focused on the fine sand until recently[3,7]; some of the researches have conducted to investigate the potential and feasibility of MICP on the tropical residue soil[8,9].

The objective of this paper is to provide better understanding of this technique by investigating the relation between the bacteria, cementation reagents, and tropical residue soil as well as to investigate the effectives and feasibility of Bacillus subtilis in this biomediated soil improvement. 


\section{Biological Processes in Biomediated Soil Improvement}

The Biomediated soil improvement started when both of the bacteria and chemical reagents were mixed together into the soil. The role of the bacteria in this process is to perform the urea hydrolysis where the supplied urea was decomposed into ammonium ion by its urease enzyme.

$\mathrm{CO}\left(\mathrm{NH}_{2}\right)^{2}+2 \mathrm{H}_{2} \mathrm{O} \longrightarrow 2 \mathrm{NH}_{4}{ }^{+}+\mathrm{CO}_{3}{ }^{2-}$

The $\mathrm{pH}$ of the soil was increased with the presence of the ammonium ion, and created a favorable environment for the calcite precipitation. Meanwhile, the carbonate ion combined with the supplied calcium ion to form the calcite precipitation.

$\mathrm{Ca}^{2+}+\mathrm{CO}_{3}{ }^{2-} \longrightarrow \mathrm{CaCO}_{3}$

The formation of calcite $\left(\mathrm{CaCO}_{3}\right)$ precipitation improved the shear strength and permeability of the treated soil; the former is achieved by biocementation which binds the soil particles together and the latter is achieved by bioclogging which fills the void between the soil particles. Both of the biocementation and bioclogging happen concurrently during the MICP treatment.

\section{Material and Methodology}

Type of Bacteria. Bacillus subtilis (ATCC 55422) is a type of facultative anaerobe bacteria which is capable to survive with and without oxygen. The diameter of the bacterium is about 2 um of a round shaped, and with gram positive bacterium.

Cementation reagent. The cementation reagents were essential material in forming the Microbial induced Calcite Precipitation (MICP). Analytical Reagents grade was adopted throughout the process to ensure the quality and consistency of the research. Cementation reagents such as urea, and calcium carbonate were prepared at $0.25 \mathrm{M}$ concentration and $3 \mathrm{~g} / \mathrm{L}$ nutrient broth was added as the supplement in this study.

Laboratory Setup /Placement of microorganism. Chemical reagents were filled on the top of the special prefabricated PVC mould (as illustrated in the Fig.1). The cementation reagents were absorbed and infiltrated into the compacted soil with help of the atmosphere pressure. The soil samples were always kept overtopped with the chemical reagent to ensure it was always in the saturated condition and avoid any potential loss due to evaporation or leakages.

Soil Specimen. The tropical residual soil specimen used in this research was retrieved at Faculty of Electrical Engineering, University Technology Malaysia. The physical and engineering properties of the tropical residual soil specimens were determined in accordance to the British Standard (BS1377) as tabulated in table 1.

Table 1 Physical Properties of the tropical residual soil

\begin{tabular}{|l|c|}
\hline \multicolumn{1}{|c|}{ Properties } & Value \\
\hline Maximum Dry Density, MDD & $1320 \mathrm{~kg} / \mathrm{m}^{3}$ \\
\hline Liquid Limit (\%) & 85.13 \\
\hline Plastic Limit (\%) & 57.8 \\
\hline Grain Size & $23.31 \%$ Sand, $16.54 \%$ Silt, \\
& $60.15 \%$ Clay \\
\hline
\end{tabular}




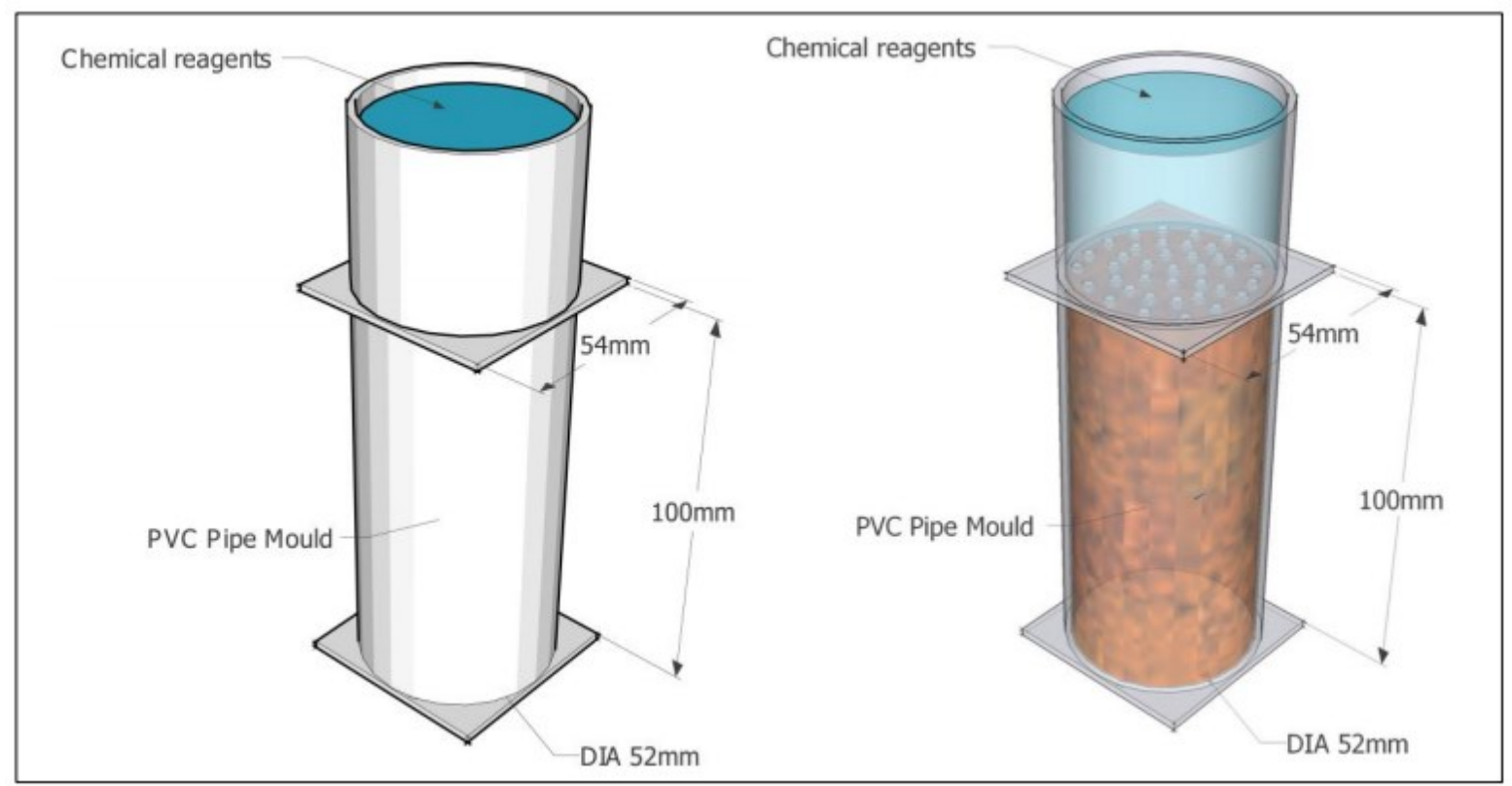

Fig.1 Overview of the Fabricated PVC mould

Soil Treatment Procedures. B.subtilis was cultivated in nutrient broth and incubated at $37^{\circ} \mathrm{C}$ with 150 revolution per minutes for 24 hours (approximately at $6 \times 10^{5} \mathrm{cfu} / \mathrm{ml}$ ) prior to the microorganism placement process. The tropical residual soil was mixed thoroughly with the cultivated bacteria and compacted into a prefabricated $52 \mathrm{~mm}$ diameter of PVC mould. It was compacted in three layers by hand tamping method at the desired density of $1188 \mathrm{~kg} / \mathrm{m}^{3}(90 \%$ of maximum dry density). Treatment was started by filling the chemical reagents at the top of the mould (Fig. 1) for 2 days to ensure the sample was entirely saturated. After 2 days of treatment, the treated soil samples were extruded for shear strength determination by using unconfined compression test (UCT).

Experimental Variables. 4 different treatment conditions were considered in this study. 1) Control specimen in which the specimen was supplied and saturated with distilled water only, 2) Specimen treated with chemical reagents only, 3) specimen was treated with bacteria only, 4) both bacteria and chemical reagents ware added to the soil. All of the samples were treated at $0.25 \mathrm{M}$ of urea and calcium chloride.

\section{Result and Discussions}

Fig. 2 showed the shear strength of treated soil under various treatment conditions. The unconfined compressive strength of the untreated residual tropical soil (control) was 10.02kPa.As Seen in Fig.2, the injection of the chemical reagent to the tropical residue soil has literally improved the shear strength of the treated soil about $31.3 \%$ from $10.02 \mathrm{kPa}$ to $13.16 \mathrm{kPa}$, which correspondingly implying that the existing bacteria inhabited in the tropical residue soil has favored the treatment process. Meanwhile, the presence of both bacteria and chemical reagent literally increase the shear strength of the biotreated soil with $78.5 \%$ of increment as compared to the control specimen. This outcome also suggested that the introduction of Bacillus subtilis is evidently favorable and feasible to the MICP process. The most striking result to emerge from the data is that the soil sample treated with bacteria only has exhibited the highest strength among the other, with $115.8 \%$ of increment of the shear strength after the treatment. This result is different with other published research in which 
the highest shear strength was achieved with the presence of both bacteria and cementation reagent $[6,8]$.it was believed that the injected chemical reagents might have caused some undesirable effect which hindered the growth of this particular bacterium and subsequently affected on the development of MICP. Another possible explanation for this phenomenon is that the component of the chemical reagents might have weakened the bonding and mineralogy of tropical residue soil particles and resulting in a slightly reduction of its shear strength after the treatment. Besides that, the retained dead cell of the bacteria in the sample could have increased the shear strength of the treated soil [10]. Further investigation on the chemical effect to the soil mineralogy, dead bacteria cell and bonding should be conducted to clarify the aforementioned matter.

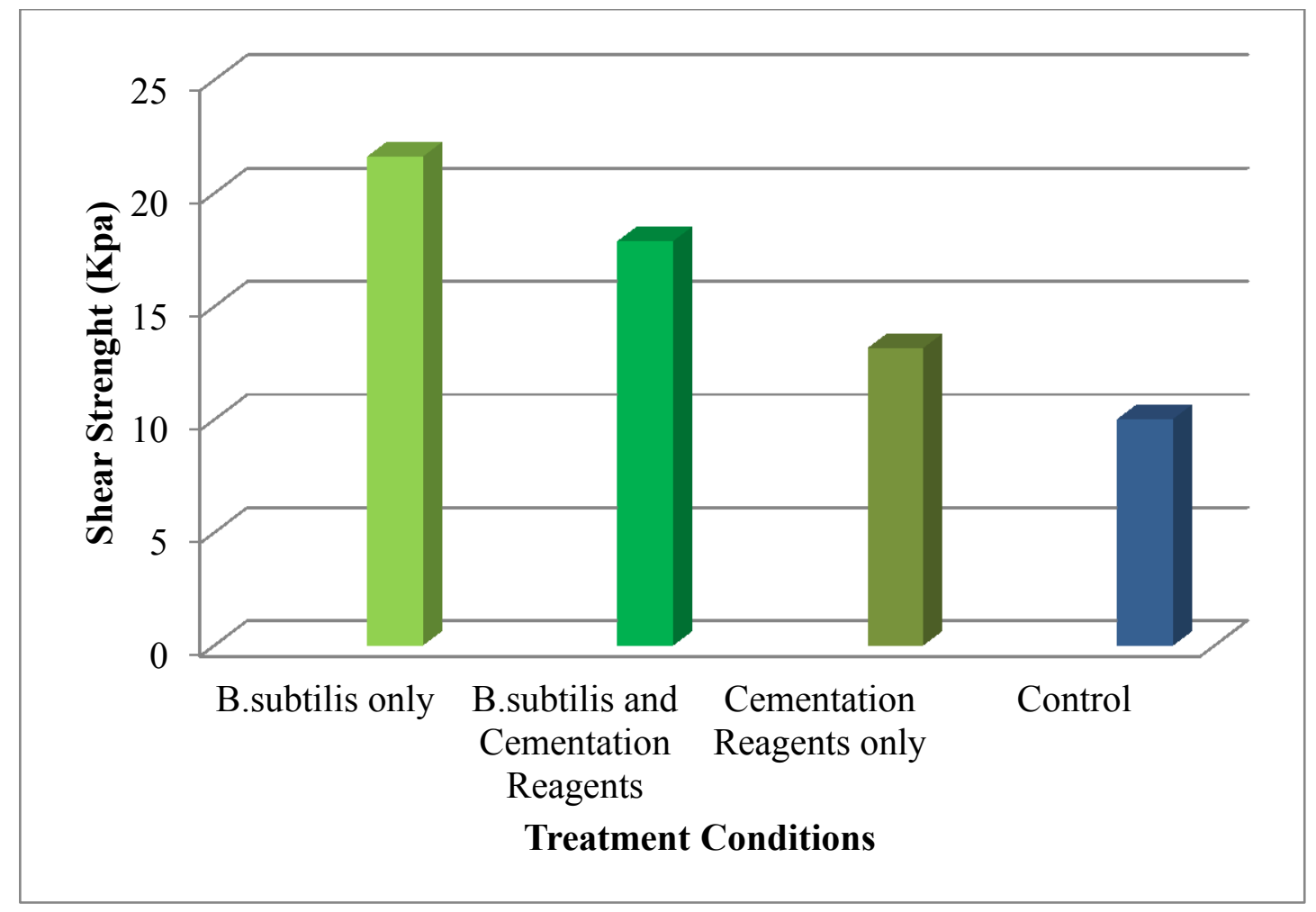

Fig.2 Shear strength and the treatment conditions

\section{Conclusion}

In this present preliminary test, the introduction of the Bacillus Subtilis in this biomediated soil improvement has proven its feasibility and effectiveness with significant improvement of shear strength. The results also indicated that the presence of the chemical reagents is effective in this technique. The presence of both bacteria and chemical reagents are favorable in this process; although, the highest improvement of shear strength was achieved with sample which was treated with bacteria only. For that reason, further profound study is required to examine the effect of the chemical reagents to the bacteria and the mineralogy of tropical residual soil.

\section{Acknowledgement.}

This project is supported by Ministry of Higher Education (MOHE), Ministry of Science, Technology and Innovation (MOSTI), Malaysia and Universiti Teknologi Malaysia under E science Fund (R.J130000.7913.4S053). 


\section{References}

[1] N., Soon, et al.: Factors Affecting Improvement in Engineering Properties of Residual Soil through Microbial-Induced Calcite Precipitation, Journal of Geotechnical and Geoenvironmental Engineering, (2014) 140(5): p. 04014006.

[2] L.A., Van Paassen, et al.: Potential soil reinforcement by biological denitrification. Ecological Engineering, (2010) 36(2): p. 168-175.

[3] J.T., DeJong, et al.: Bio-mediated soil improvement, Ecological Engineering, (2010) 36(2): p. 197-210.

[4] M., Naeimi, et al.: Development of Microbial Geotechnology in Singapore, Geo-Frontiers (2011) p. 4070-4078.

[5] V., Ivanov, et al: Iron-Based Bio-Grout For Soil Improvement and Land Reclamation, Second International Conference on Sustainable Construction Materials and Technologies, (2010), The University of Wisconsin Milwaukee Centre.

[6] N.W., Soon, et al.: Improvements in Engineering Properties of Soils Through Microbial Induced Calcite Precipitation, KSCE Journal of Civil Engineering, (2013) 17(4): p. 1-11.

[7] J., DeJong, M. Fritzges, and K. Nüsslein: Microbially Induced Cementation to Control Sand Response to Undrained Shear, Journal of Geotechnical and Geoenvironmental Engineering, (2006) 132(11): p. 1381-1392.

[8] W.S., Ng, M.L. Lee, and S.L. Hii: An Overview of the Factors Affecting Microbial-Induced Calcite Precipitation and its Potential Application in Soil Improvement, World Academy of Science, Engineering and Technology, (2012).

[9] M.L., Lee, W.S. Ng, and Y. Tanaka: Stress-deformation and compressibility responses of bio-mediated residual soils, Ecological Engineering, (2013) 60(0): p. 142-149.

[10] C.W., Chou, Seagren,E.A.,A.H., and Lai,M. (2011): Biocalcification of sand through ureolysis, J.Geotech.Geoenviron.Eng.,10.1061/(ASCE).GT.1943-5606.0000532,1179-1189. 